\title{
TANGGUNG JAWAB PELAKU USAHA TERHADAP KONSUMEN DALAM HAL TERJADINYA HORTWEIGHTING DITINJAU DARI UNDANG-UNDANG RI NO 8 TAHUN 1999 TENTANG PERLINDUNGAN KONSUMEN
}

\author{
Oleh : \\ Ni Komang Ayu Nira Relies Rianti ${ }^{1}$
}

\begin{abstract}
Shortweighting is one of the selling practices of goods that harm consumers. Where the actual weight of the item is less than the weight indicated on the goods packaging label. Clearly, consumers are severely disadvantaged as a result of changes in the goods made by businessmen. With The result that consumers get goods that are not in accordance with the conditions and the promised warranty or stated on the label. The legal issues in this writing are 1. How is the liability of businessmen to consumers in the case of short-weighting reviewed by Law No. 8 of 1999? and 2. What kind of dispute settlement efforts that can be taken by the consumer in case of short-weighting? This research is normative legal research. The conclusion of this study is that the businessmen are to be responsible if proven to occur sales practice short-weighting. It is contained in Article 19 of Law No. 8 of 1999 on Consumer Protection. The legal efforts to resolve disputes that can be reached by consumers can be through 2 (two) ways of settling disputes, outside the court or alternative dispute resolution and settlement of litigation. The settlement of disputes outside the court can be through the settlement of disputes solved by deliberation by the parties and could be through the Indonesia Consumer Dispute Settlement Institution (BPSK).
\end{abstract}

Keywords: Shortweighting, Bussinessmen, Consumer Protection

\begin{abstract}
Abstrak
Shortweighting adalah salah satu praktek penjualan barang yang merugikan konsumen. Dimana berat barang yang sebenarnya adalah lebih kecil dari berat yang tertera pada label kemasan barang. Jelas sekali bahwa konsumen sangat dirugikan akibat adanya perubahan barang tersebut yang dilakukan oleh pelaku usaha. Sehingga konsumen mendapatkan barang yang tidak sesuai dengan kondisi dan jaminan yang dijanjikan atau yang dinyatakan dalam label. Rumusan masalah dalam penulisan ini adalah 1. Bagaimanakah tanggungjawab pelaku usaha terhadap konsumen dalam hal terjadinya shortweighting ditinjau dari Undang-Undang Nomor 8 Tahun 1999? dan 2. Apakah upaya penyelesaian sengketa yang dapat ditempuh oleh konsumen bila terjadi shortweighting? Jenis penelitian yang digunakan adalah jenis penelitian hukum normatif. Kesimpulan dari hasil penulisan penelitian ini bahwa pelaku usaha bertanggung jawab apabila terbukti terjadi praktik penjualan shortweighting. Hal tersebut tertuang
\end{abstract}

1 PT PLN (Persero) Distribusi Bali pada Bidang Pengadaan. Email : lies_rianti@yahoo.com 
dalam Pasal 19 Undang-Undang Nomor 8 Tahun 1999 tentang Perlindungan Konsumen. Upaya penyelesaian sengketa yang dapat ditempuh konsumen dapat melalui 2 (dua) cara yaitu penyelesaian sengketa diluar pengadilan dan penyelesaian litigasi. Penyelesaian sengketa di luar pengadilan yaitu bisa melalui penyelesaian sengketa secara damai oleh pihak sendiri dan bisa melalui Badan Penyelesaian Sengketa Konsumen (BPSK).

\section{Kata kunci : Shortweighthing, Pelaku Usaha, Perlindungan Konsumen}

\section{PENDAHULUAN}

Dewasa ini bangsa Indonesia sedang giat melaksanakan pembangunan ekonomi untuk dapat segera keluar dari krisis ekonomi yang berkepanjangan. Pembangunan nasional ini bertujuan untuk mewujudkan suatu masyarakat adil dan makmur yang merata materiil dan spiritual dalam era demokrasi ekonomi berdasarkan Pancasila dan UndangUndang Dasar 1945. Bahwa untuk meningkatkan harkat dan martabat konsumen perlu meningkatkan kesadaran, pengetahuan, kepedulian, kemampuan dan kemandirian konsumen untuk melindungi dirinya serta menumbuh kembangkan sikap pelaku usaha yang bertanggung jawab.

Pepatah Indonesia "pembeli adalah raja" ternyata cuma jadi pemanis bibir. Yang terjadi justru sebaliknya, para konsumen lah kerap menjadi buak atau korban. Dulu kedudukan konsumen lebih rendah dari pada pelaku usaha, konsumen tidak dapat memperoleh apa yang sebenarnya menjadi haknya. Konsumen hanya dapat menerima saja yang dilakukan dan apapun yang menjadi keputusan pelaku usaha. Pelaku usaha bebas untuk membuat dan menetapkan segala peraturan secara sepihak atas barang dan jasa yang diproduksi atau diperdagangkan nya. Hal tersebut sering terjadi karena pada saat itu belum adanya peraturan khusus di bidang perlindungan konsumen.

Masyarakat Indonesia baik pelaku bisnis maupun pihak konsumen menginginkan ada sebuah Undangundang yang secara komprehensif mengatur hubungan antara penjual maupun pembeli. Keinginan tersebut didorong oleh munculnya praktikpraktik perdagangan yang tidak sehat. Praktik-praktikperdaganganyang tidak sehat tersebut, dapat menimbulkan kerugian bagi konsumen.

Contoh kasus nyata menjelang Lebaran tahun 2007, penjualan biskuit yang dikemas dalam kaleng berisi $700 \mathrm{~g}$ dan biasanya penuh satu kaleng. ${ }^{2}$ Namun betapa kagetnya ketika YLKI menemukan biskuit yang sama, ternyata biskuit itu dibungkus satu per satu dalam plastik sehingga terkesan memenuhi kemasan kaleng. Ketika dibuka dari plastiknya dan dimasukan kedalam kaleng, isinya

2 Sularsi, SH, Senior Staff YLKI, http://ylki. or.id/2011/11/membeli-barang-dalamkeadaan-terbungkus, diakses 4 Desember 2017 Pukul 16.30 Wita. 
tidak akan lebih dari separuh kaleng. Jika konsumen hanya berpatokan pada fisik kemasannya maka akan salah besar. Hal ini merupakan merugikan konsumen, maka patut diwaspadai oleh konsumen serta perlunya pengawasan oleh instansi yang terkait agar tidak terjadi misleading.

Salah satu contoh lainnya kasus shortweighting yang terjadi di Indonesia adalah pengoplosan gas LPG. Sebagaimana berita yang dirilis oleh metronews.com dalam media online tanggal 4 Oktober $2017^{3}$, terungkapnya ledakan Gudang Elpiji di Karang Tengah merupakan salah satu dugaan adanya tindakan pelaku usaha yang merugikan konsumen. Dari hasil penyelidikan kepolisian diduga telah terjadi praktik pengoplosan elpiji, yakni dari tabung $3 \mathrm{Kg}$ ke tabung LPG $12 \mathrm{Kg}$ dan $50 \mathrm{Kg}$.

Menurut Rachmadi Usman perlu diberlakukan suatu sistem pengawasan dengan diwajibkannya "wajib uji makanan". Wajib ini tidak hanya meliputi persyaratan mutu, tetapi juga mengenai hal-hal lain yang penting dalam usaha memberikan perlindungan konsumen seperti wajib dafar makanan dan minuman, masalah kemasan, masalah label serta tanggung jawab produsen. ${ }^{4}$ Dikaitkan dengan hal tersebut di atas, maka pemerintah mengeluarkan undang-undang

3 YDH, 2017, http://news.metrotvnews.com/ $\mathrm{read} / 2017 / 10 / 04 / 767975 /$ ylki-minta-polisiusut-ledakan-gudang-pengisian-elpiji, diakses tanggal 4 Desember 2017 Pukul 16.35 Wita.

4 Rachmadi Usman, 2004, Hukum Persaingan Usaha di Indonesia, PT. Gramedia Pustaka Utama, Jakarta, hlm. 1. khusus yang mengatur mengenai perlindungan konsumen yaitu UndangUndang Nomor 8 Tahun 1999 yang diundangkan pada tanggal 20 April dalam Lembaran Negara Tahun 1999 Nomor 42, tambahan Lembaran Negara Nomor 3821, dengan tujuan agar hak-hak konsumen dilindungi serta mengangkat martabat konsumen dengan cara menghindarkannya dari akses negatif pemakaian barang dan/ atau jasa

Seiring dengan diundangkannya Undang-Undang Perlindungan Konsumen tersebut, maka hak-hak konsumen lebih diperhatikan, salah satunya adalah hak atas informasi yang benar, jelas dan jujur mengenai kondisi dan jaminan barang dan/atau jasa serta hak untuk mendapatkan advokasi, perlindungan dan upaya penyelesaian sengketa perlindungan konsumen secara patut.

Konsumen berkepentingan akan perlindungan hukum sehubungan dengan kualitas maupun kuantitas barang dan/jasa. Sebuah kenyataan bahwa konsumen menduduki posisi yang cukup penting di dalam kelangsungan roda perekonomian. Namun sangat di sayangkan bahwa kedudukan konsumen justru berada di posisi lemah di bandingkan dengan pelaku usaha dalam hal perlindungan konsumen.

Menurut pasal 1 huruf 2 Undang-Undang Nomor 8 Tahun 1999 berbunyi: "Konsumen adalah setiap orang pemakai barang dan/ jasa yang 
tersedia dalam masyarakat, baik bagi kepentingan diri sendiri, keluarga, orang lain maupun mahluk hidup lain, dan untuk tidak diperdagangkan. Yusuf Shofie menjelaskan bahwa masyarakat yang diartikan sebagai konsumen, tidak selalu harus memberikan prestasinya dengan cara membayar uang untuk memperoleh barang dan/atau jasa. Dengan kata lain, dasar hubungan hukum antara konsumen dan pelaku usaha tidak perlu kontraktual (the privity of contract). ${ }^{5}$

Bertolak dari luas dan kompleknya hubungan antara pelaku usaha dan konsumen, maka untuk melindungi konsumen sebagai pemakai akhir produk barang dan/jasa membutuhkan berbagai aspek hukum agar benar-benar dapat dilindungi dengan adil. Sejak awal produksi, perlindungan konsumen sudah harus dimulai. Dan peran pemerintah sangat diperlukan dalam rangka melindungi kepentingan konsumen pada umumnya.

Menurut Yusuf Shofie, keberadaan UUPK di tengah-tengah globalisasi saat ini justru merupakan instrumen hukum yang tidak hanya berfungsi untuk melindungi kepentingan hukum konsumen melainkan juga kepentingan hukum bagi pelaku usaha. Merujuk pada penjelasan umum UUPK, yaitu: ${ }^{6}$

5 Yusuf Sofie, 2000, Perlindungan Konsumen Dan Instrumen-instrumen Hukumnya, PT. Citra Aditya Bakti, Bandung, hlm. 250.

$6 \quad$ Ibid, hlm. 8.
1. Kedudukan pelaku usaha dan konsumen tidak seimbang dan konsumen berada di posisi lemah.

2. Prinsip ekonomi pelaku usaha untuk mendapatkan keuntungan yang semaksimal mungkin dengan modal seminimal mungkin, sangat potensial merugikan konsumen baik secara langsung maupun tidak langsung.

Kemudian Endang Sri Wahyuni, menyatakanlemahnyaposisikonsumen dibandingkan dengan pelaku usaha dikarenakan sangat sedikit konsumen yang mengetahui tentang hak-haknya. Hal ini disebabkan karena minimnya pendidikan, dan pengetahuan serta kemampuan hukum dan ekonomi dari konsumen yang umumnya adalah

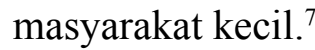

Perlindungan konsumen di Indonesia jika diteliti lebih jelas lagi belum sepenuhnya dapat terwujud, walaupun telah ada undang-undang yang mengaturnya, tetap saja pelaku usaha dapat berbuat semaunya terhadap barang dan/jasa yang ia tawarkan kepada konsumen. Begitu banyak kecurangan-kecurangan yang pelaku usaha lakukan guna untuk mendapatkan keuntungan yang besar atas penjualan barang dan/jasa yang mereka produksi atau diperdagangkan. Salah satunya adalah kasus adanya

7 Endang Sri Wahyuni, 2003, Aspek Hukum Sertifikasi Dan Keterkaitannya Dengan Perlindungan Konsumen, PT. Citra Aditya Bakti, Bandung, hlm.96. 
ketidak sesuaian berat bersih suatu barang yang tertera pada label dengan kenyataan yang sesungguhnya ( untuk selanjutnya disebut shortweighting). Shortweighting adalah salah satu praktik penjualan barang yang merugikan konsumen. Dimana berat barang yang sebenarnya adalah lebih kecil dari berat yang tertera pada label kemasan barang. ${ }^{8}$

Jelas sekali terlihat bahwa konsumen sangat dirugikan akibat adanya perubahan barang tersebut yang dilakukan oleh pelaku usaha. Sehingga konsumen mendapatkan barang yang tidak sesuai dengan kondisi dan jaminan yang dijanjikan atau yang dinyatakan dalam label.

Menurut pasal 8 ayat (1) butir b Undang-undang Nomor 8 Tahun 1999 tentang Perlindungan Konsumen, menyebutkan bahwa : "Pelaku usaha dilarang memproduksi dan/ memperdagangkan barang dan/jasa yang tidak sesuai dengan berat bersih, isi bersih atau netto, dan jumlah dalam hitungan sebagaimana yang dinyatakan dalam label atau etiket barang tersebut".

Konsekuensi hukum dari pelanggaran yang diberikan oleh Undang-Undang Nomor 8 Tahun 1999 tentang Perlindungan Konsumen, dan sifat perdata dari hubungan hukum antara pelaku usaha dan konsumen, maka demi hukum setiap pelanggaran yang dilakukan oleh pelaku usaha yang merugikan konsumen,

8 Ujang Sumarwan, 2002, Perilaku Konsumen Teori Dan Penerapannya Dalam Pemasaran, Ghalia Indonesia, Bogor, hlm. 334. memberikan hak kepada konsumen yang dirugikan tersebut untuk meminta pertanggungjawaban dari pelaku usaha yang merugikannya serta untuk menuntut ganti rugi atas kerugian yang diderita oleh konsumen tersebut.

Berdasarkan latar belakang tersebut diatas, maka dapat dirumuskan suatu permasalahan sebagai berikut:

1. Bagaimanakah tanggungjawab pelaku usaha terhadap konsumen dalam hal terjadinya shortweighting ditinjau dari Undang-Undang Nomor 8 Tahun 1999?

2. Apakah upaya penyelesaian sengketa yang dapat ditempuh oleh konsumen bila terjadi shortweighting?

Penelitian ini merupakan karya ilmiah asli yang belum pernah diteliti sebelumnya. Adapun karya ilmiah yang terkait dengan karya ilmiah yang Penulis tulis yaitu: Pertama, oleh Gde Manik Yogiartha tahun 2016 yang berjudul Tanggungjawab Pelaku Usaha Terkait Dengan JualBeli Telepon Seluler Tanpa Garansi yang menggambarkan bagaimana tanggungjawab pelaku usaha terhadap transaksi jual-beli telepon seluler tanpa garansi serta sanksi hukum bagi pelaku usaha tersebut. ${ }^{9}$ Kedua, oleh Ni Putu Januaryanti Pande tahun 2017

9 Gde Manik Yogiartha, Tanggungjawab Pelaku Usaha Terkait Dengan Jual-Beli Telepon Seluler Tanpa Garansi. Jurnal Magister Hukum Udayana (Udayana Master Law Journal), vol 5 no.1 edisi mei 2016. https://ojs.unud.ac.id/ index.php/jmhu/article/view/20613/14457. diakses tanggal 20 November 2017.doi:https:// doi.org/10.24843/JMHU.2016.v05.i01.p09. 
dengan judul Perlindungan Konsumen Terhadap Produk Kosmetik Impor Yang Tidak Terdaftar Di BBPOM Denpasar yang menggambarkan pada implementasi perlindungan hukum terhadap konsumen yang menderita kerugian akibat kosmetik Impor yang tidak terdaftar di BBPOM Denpasar serta faktor-faktor yang mempengaruhi beredarnya kosmetik tersebut. ${ }^{10}$ Selanjutnya ketiga, karya ilmiah yang ditulis oleh Agus Brotosusilo Tahun 1992 yang berjudul Hak-hak Produsen Dalam Hukum Perlindungan Konsumen yang lebih menekankan perlindungan konsumen yang ditinjau dari hak produsen secara umum. ${ }^{11}$ Jelas nampak perbedaan dari karya ilmiah tersebut dengan karya ilmiah yang dibuat oleh Penulis. Dari ketiga karya ilmiah terdahulu diatas belum satupun yang menganalisa tentang tanggung jawab pelaku usaha dalam hal terjadi shortweighting.

Tujuan dari penelitian ini adalah untuk memberikan gambaran yang jelas tentang bentuk perlindungan hukum terhadap konsumen dalam hal

10 Ni Putu Januaryanti Pande, Perlindungan Konsumen Terhadap Produk Kosmetik Impor Yang Tidak Terdaftar Di BBPOM Denpasar. Jurnal Magister Hukum Udayana (Udayana Master Law Journal), vol.6 no.1 edisi mei 2017, https://ojs.unud.ac.id/index.php/jmhu/ article/view/22288/20922. diakses tanggal 20 November 2017. doi:https://doi.org/10.24843/ JMHU.2017.v06.i01.p02.

11 Agus Brotosusilo, Hak-Hak Produsen Dalam Hukum Perlindungan Konsumen, Jurnal Hukum dan Pembangunan, vol. 22 no.5 tahun 1992, http://www.jhp.ui.ac.id/index. $\mathrm{php} /$ home/article/view/1011, diakses tanggal 20 November 2017. Doi:http://dx.doi. org/10.21143/jhp/vol22.no5.1011 terjadinya shortweighting serta upaya penyelesaian sengketa yang dapat ditempuh.

\section{METODE PENELITIAN}

Metode penelitian hukum adalah sebagai cara kerja keilmuan yang salah satunya ditandai dengan menggunakan metode (dalam bahasa Yunani disebut Methodos, Meta berarti diatas, sedangkan thodos berarti suatu jalan, suatu cara). ${ }^{12}$ Apabila dilihat dari jenisnya, maka penelitian hukum dapat dibedakan menjadi tiga jenis yaitu : penelitian hukum normatif, penelitian hukum empiris, atau gabungan keduanya. ${ }^{13}$ Penulisan karya ilmiah ini menggunakan jenis penelitian hukum normatif. Penelitian hukum normatif artinya penelitian yang bertitik berat terhadap bahan hukum berupa aturan atau norma hukum positif dan menjadi bahan acuan utama dalam penelitian. ${ }^{14}$ Sedangkan pendekatan yang digunakan dalam penelitian ini adalah pendekatan perundang-undangan (the statute approach) yaitu mengkaji semua undang-undang dan peraturan yang berhubungan dengan isu hukum yang sedang diteliti. Bahan hukum yang digunakan terdiri dari bahan hukum primer, bahan hukum sekunder, dan bahan hukum tersier.

12 Jhony Ibrahim, 2006, Teori dan Metodeologi Penelitian Hukum Normatif, Bayu Publishing, Malang, hlm. 26.

13 Soerjono Soekanto, 2006, Pengantar Penelitian Hukum, UII Press, Jakarta, hlm. 201.

14 Ibid. 
III. HASIL DAN PEMBAHASAN

3.1 Tanggungjawab Pelaku Usaha Dalam Hal Terjadi Shortweighting ditinjau dari Undang-Undang Nomor 8 Tahun 1999

Konsumen menurut pasal 1 angka 1 Undang-Undang tentang Perlindungan Konsumen adalah "setiap orang pemakai barang dan/atau jasa yang tersedia dalam masyarakat, baik bagi kepentingan diri sendiri, orang lain, maupun makhluk hidup lain dan tidak untuk diperdagangkan”.

Hak konsumen dalam UndangUndang Perlindungan Konsumen Nomor 8 Tahun 1999 pada Bab III Bagian Pertama pasal 4, yaitu konsumen mempunyai hak sebagai berikut :

a) Hak atas kenyamanan, keamanan dan keselamatan dalam mengkonsumsi barang dan/atau jasa;

b) hak untuk memilih barang dan/ atau jasa serta mendapatkan barang dan/atau jasa tersebut sesuai dengan nilai tukar dan kondisi serta jaminan yang dijanjikan;

c) hak atas informasi yang benar, jelas dan jujur mengenai kondisi dan jaminan barang dan/atau jasa;

d) hak untuk didengar pendapat dan keluhannya atas barang dan/jasa yang digunakan;

e) hak untuk mendapatkan advokasi, perlindungan, dan upaya penyelesaian sengketa perlindungan konsumen secara patut;

f) hak untuk mendapat pembinaan dan pendidikan konsumen;

g) hak untuk diperlakukan atau dilayani secara benar dan jujur serta tidak diskriminatif;

h) hak untuk mendapatkan kompensasi, ganti rugi dan/atau penggantian, apabila barang dan/atau jasa yang diterima tidak sesuai dengan perjanjian atau tidak sebagaimana mestinya;

i) hak-hak yang diatur dalam ketentuan peraturan perundangundangan lainnya.

Pengaturan mengenai kewajiban konsumen, terdapat dalam pasal 5 Undang-Undang tentang Perlindungan Konsumen, yang menyebutkan bahwa kewajiban konsumen antara lain :

a) Membaca atau mengikuti petunjuk informasi dan prosedur pemakaian atau pemanfaatan barang dan/atau jasa, demi keamanan dan keselamatan.

b) Beritikad baik dalam melakukan transaksi pembelian barang dan/ atau jasa

c) Membayar sesuai dengan nilai tukar yang disepakati.

d) Mengikuti upaya penyelesaian hukum sengketa perlindungan konsumen secara patut.

Pasal 1 angka 3 UndangUndang Perlindungan Konsumen, menyebutkan: 
Pelaku usaha adalah setiap orang perorangan atau badan usaha, baik yang berbentuk badan hukum maupun bukan badan hukum yang didirikan dan berkedudukan atau melakukan kegiatan dalam wilayah hukum Negara Republik Indonesia, baik sendiri maupun bersama melalui perjanjian menyelenggarakan kegiatan usaha dalam berbagai bidang ekonomi. Pelaku usaha yang dimaksudkan dalam pengertian ini adalah perusahaan, korporasi, BUMN, koperasi, importer, pedagang, distributor, dan lain-lain.

Sama seperti halnya pemberian hak dan kewajiban kepada konsumen, undang-undang juga memberikan hak dan kewajiban kepada pelaku usaha. Dalam Bab III mengenai hak dan kewajiban pelaku usaha, Bagian Kedua Pasal 6, menyebutkan bahwa hak-hak pelaku usaha adalah :

a. Hakuntukmenerimapembayaran yang sesuai dengan kesepakatan mengenai kondisi dan nilai tukar barang dan/atau jasa yang diperdagangkan;

b. Hak untuk mendapat perlindungan hukum dari tindakan konsumen yang beritikad tidak baik;

c. Hak untuk melakukan pembelaan diri sepatunya di dalam penyelesaian hukum sengketa konsumen;

d. Hak untuk rehabilitasi nama baik apabila terbukti secara hukum bahwa kerugian konsumen tidak diakibatkan oleh barang dan/atau jasa yang diperdagangkan; e. Hak-hak yang diatur dalam ketentuan peraturan perundangundangan lainnya.

Selain mempunyai hak-hak yang harus dipenuhi, pelaku usaha juga mempunyai kewajiban-kewajiban yang harus dilakukan. Kewajiban pelaku usaha tersebut diatur dalam pasal 7 Undang-Undang Perlindungan Konsumen, yang menyebutkan bahwa kewajiban pelaku usaha adalah :

a. Beritikad baik dalam melakukan kegiatan usahanya;

b. Memberikan informasi yang benar, jelas dan jujur mengenai kondisi dan jaminan barang dan/atau jasa serta memberikan penjelasan penggunaan, perbaikan, dan pemeliharaan;

c. Memperlakukan atau melayani konsumen secara benar dan jujur serta tidak diskriminatif;

d. Menjamin mutu barang dan/atau jasa yang diproduksi dan/atau diperdagangkan berdasarkan ketentuan standar mutu barang dan/atau jasa yang berlaku;

e. Memberi kesempatan kepada konsumen untuk menguji, dan/ atau mencoba barang dan/atau jasa tertentu serta memberi jaminan dan/atau garansi atas barang yang dibuat dan/atau yang diperdagangkan;

f. Memberi kompensasi, ganti rugi, dan/atau penggantian atas kerugian akibat penggunaan, pemakaian, dan pemanfaatan barang dan/atau jasa yang diperdagangkan; 
g. Memberi kompensasi, ganti rugi, dan/atau penggantian apabila barang dan/atau jasa yang diterima atau dimanfaatkan tidak sesuai dengan perjanjian.

Aspek hukum perlindungan konsumen jika dikaitnya dengan Undang-Undang Nomor 8 Tahun 1999 tentang Hukum Perlindungan Konsumen, mengenakan hak dan kewajiban bagi pelaku usaha di dalam memenuhi tuntutan untuk menciptakan produk yang berkualitas.

Rajagukguk Erman menyatakan tidak adanya atau kurangnya kesadaran akan tanggung jawabnya sebagai pelaku usaha akan berakibat fatal dan menghadapi risiko bagi kelangsungan hidup atau kredibilitas usahanya. Rendahnya kualitas produk atau adanya cacat produk yang dipasarkan sehingga menyebabkan kerugian pada konsumen. Di samping akan menghadapi kompensasi (ganti rugi), juga akan berakibat bahwa produk tersebut akan kalah bersaing dalam merebut pasar. Sehingga perlu dilakukannya pembaharuan hukum yang berkaitan dengan produk liability terutama dalam rangka mempermudah pemberian ganti rugi bagi konsumen yang menderita kerugian akibat produk yang diedarkan di masyarakat. ${ }^{15}$

Selain itu dalam UndangUndang Nomor 8 Tahun 1999, juga mengatur mengenai perbuatan yang

15 Rajagukguk Erman, 2000, Hukum Perlindungan Konsumen, Mandar Maju, Bandung, hlm. 43. dilarang bagi pelaku usaha yaitu dalam Pasal 8 Undang-Undang Perlindungan Konsumen. Pasal 8 ayat (1) butir b, merupakan dasar hukum yang tidak memperbolehkan adanya praktikpraktik penjualan makanan yang menggunakan cara yang tidak sesuai. Salah satu praktik penjualan barang yang dilarang oleh Undang-Undang Perlindungan Konsumen adalah praktik penjualan barang dengan cara shortweighting.

Shortweighting adalah salah satu praktik penjualan barang yang merugikan konsumen, dimana berat barang yang sebenarnya adalah lebih kecil dari berat yang tertera pada label kemasan barang. ${ }^{16}$ "Shortweighting juga dapat diartikan bahwa berat suatu barang adalah kurang dari berat/bobot yang seharusnya". ${ }^{17}$ Hal yang sama juga disebutkan oleh Menurut Ujang Sumarwan, Shortweighting adalah salah satu praktik penjualan barang yang merugikan konsumen, dimana berat barang yang sebenarnya adalah lebih kecil dari berat yang tertera pada label kemasan barang. Shortweighting juga dapat diartikan bahwa berat suatu barang adalah kurang dari berat/bobot yang seharusnya. ${ }^{18}$

Hubungan antara konsumen dengan pelaku usaha timbul suatu kerugian sebagai akibat dari penggunaan, pemanfaatan serta

$16 \quad$ Ibid, hlm. 334.

17 HRA. Rivai Wirasamita, Kamus Lengkap Ekonomi, CV Pionir Jaya, Bandung, 2002, hlm. 449.

18 Ujang Sumarwan, loc. cit. 
pemakaian atas suatu barang tertentu yangdihasilkanolehpelakuusaha, maka konsumen dalam hal ini keluhannya berhak untuk didengar. Konsumen juga berhak untuk memperoleh ganti kerugian dan sebaliknya pelaku usaha berkewajiban untuk mendengarkan keluhan konsumen dan memberi ganti rugi akibat kerugian konsumen.

Ketentuan yang dijadikan sebagai dasar hukum adanya hak untuk menuntut ganti rugi oleh konsumen kepada pelaku usaha atas kerugian yang dideritanya akibat mengkonsumsi barang dan/atau jasa yang diproduksi atau diperdagangkan oleh pelaku usaha, yaitu pasal 1365 KUH Perdata jo Pasal 1865 KUH Perdata.

Pasal 1365 KUH Perdata, menyebutkan bahwa:

"Tiap perbuatan melanggar hukum, yang membawa kerugian kepada orang lain, mewajibkan orang yang karena salahnya menerbitkan kerugian itu, mengganti kerugian tersebut.”

Pasal 1865 KUH Perdata, menyebutkan bahwa:

"Setiap orang yang mendalilkan bahwaiamempunyai sesuatuhak, atau guna meneguhkan haknya sendiri maupun membantah suatu hak orang lain, menunjuk pada suatu peristiwa, diwajibkan membuktikan adanya hak atau peristiwa tersebut".

Hubungan kontraktual tidaklah diisyaratkan jika gugatan yang diajukan konsumen berdasarkan pada
Pasal 1365 KUHPerdata, sehingga konsumen sebagai penggugat harus membuktikan unsur-unsur sebagai berikut:

a. Adanya perbuatan melawan hukum;

b. Adanya kesalahan/kelalaian pengusaha/perusahaan;

c. Adanya kerugian yang dialami konsumen;

d. Adanya hubungan kausal antara perbuatan melanggar hukum dengan kerugian yang dialami konsumen. ${ }^{19}$

Beban pembuktian dalam hal ini dihadapkan pada konsumen, dan konsumen harus membuktikan keempat unsur tersebut. Hal ini dirasakan tidak adil bagi konsumen dengan dasar pertimbangan yaitu lemahnya kedudukan konsumen dibandingkan dengan pelaku usaha. Karenanya pelaku usaha lah yang harus membuktikan bahwa ia tidak lalai dalam proses produksinya. Oleh karena beban pembuktian ada pada pelaku usaha dalam membuktikan ada atau tidaknya unsur kesalahan. Sehingga sistem pembuktian yang digunakan terhadap gugatan ganti rugi dalam penyelesaian sengketa konsumen adalah sistem pembuktian terbalik yang didasarkan pada ada tidaknya unsur kesalahan yang dilakukan oleh pelaku usaha. Hal ini sesuai dengan ketentuan dalam Pasal 19 dan Pasal 22 Undang-Undang Perlindungan Konsumen. Sedangkan

19 Rajagukguk Erman, op. cit, hlm. 66. 
mengenaitanggungjawab pelakuusaha terhadap konsumen atas tuntutan ganti rugi tertuang dalam Pasal 24 UndangUndang Perlindungan Konsumen.

Menurut Pasal 28 UndangUndang Perlindungan Konsumen "Pembuktian terhadap ada tidaknya unsur kesalahan dalam gugatan ganti rugi sebagaimana dimaksud dalam Pasal 19, Pasal 22, dan Pasal 23 merupakan beban dan tanggung jawab pelaku usaha."

Terkait hal tersebut, menurut Abdulkadir Muhammad disebutkan bahwa tanggung jawab adalah wajib, menanggung, wajib memikul beban, wajib memenuhi segala akibat yang timbul dari perbuatan, rela mengabdi, dan rela berkorban untuk kepentingan pihak lain. $^{20}$

Pelaku usaha dalam hukum perlindungan konsumen harus dapat di mintakan pertanggung jawaban, yaitu jika perbuatannya telah melanggar hak-hak dan kepentingan konsumen, menimbulkan kerugian, atau kesehatan konsumen terganggu. ${ }^{21}$

Menurut kamus hukum, "Tanggung jawab produk yaitu tanggung jawab para produsen untuk produk yang telah di bawa nya kedalam peredaran yang menimbulkan atau menyebabkan kerugian karena cacat yang melekat pada produk tersebut".

20 Abdulkadir Muhammad, 2000, Hukum Perdata Indonesia, PT. Citra Aditya Bakti, Bandung, hlm. 94.

21 Wahyu Sasongko, 2007, KetentuanKetentuan Pokok Hukum Perlindungan Konsumen,(Bandar Lampung:Penerbit Universitas Lampung), hlm. 93.
Ada 4 bentuk tanggung jawab, ${ }^{22}$ yaitu

1. Tanggung jawab berdasarkan unsur kesalahan

Teori ini menyatakan bahwa seorang baru dapat di mintakan pertanggung jawaban secara hukum jika ada unsur kesalahan yang diberlakukannya.

2. Pradugauntukselalubertanggung jawab

Teori ini menyatakan bahwa tergugat selalu dapat dianggap bertanggung jawab sampai ia dapat membuktikan bahwa ia tidak bersalah.

3. Praduga untuk tidak selalu bertanggung jawab

Teori ini adalah kebalikan dari prinsip yang kedua, dimana pelaku usaha tidak dapat diminta pertanggung jawabannya dan konsumen lah yang menanggung segala risiko. Teori praduga untuk tidak bertanggung jawab hanya dikenal dalam lingkup transaksi konsumen yang sangat terbatas.

4. Tanggung jawab mutlak

Teori tanggung jawab mutlak dalam hukum perlindungan konsumen secara umum digunakan untuk meminta pertanggung jawaban pelaku usaha yang memasarkan produknya yang merugikan konsumen. Asas tanggung jawab

22 Munir Fuady, 1996. Hukum Bisnis Dalam Teori dan Praktek, Buku Ketiga, CitraAditya Bakti, Bandung, hlm.64. 
ini lebih dikenal dengan nama product liability.

5. Tanggung jawab dengan pembatas

Teori ini sangat merugikan konsumen bila ditetapkan secara sepihak oleh pelaku usaha.

Berdasarkan poin-poin diatas dapat diartikan bahwa tanggung jawab pelaku usaha timbul karena adanya hubungan antara produsen dengan konsumen tetapi terdapat tanggung jawab masing-masing. Atas dasar keterkaitan yang berbeda maka pelaku usaha melakukan kontak dengan konsumen dengan tujuan tertentu yaitu mendapatkan keuntungan yang sebesar-besarnya dengan peningkatan produktivitas dan efisiensi. Sedangkan konsumen hubungannya untuk memenuhi tuntutan kebutuhan hidup.

Berdasarkan pada ketentuan pasal-pasal dalam undang-undang perlindungan konsumen bahwa pelaku usaha langsung dianggap bersalah jika terjadi kasus gugatan ganti rugi sehingga di dalamnya di anut prinsip praduga bersalah. Oleh karena pelaku usaha harus bertanggungjawab memberi ganti kerugian secara langsung kepada konsumen. ${ }^{23}$

Pelaku usaha dengan demikian harus bertanggung jawab dan menanggung risiko apabila terbukti yaitu keadaan yang disebabkan oleh

23 Susanti Adi Nugroho, 2008, Proses Penyelesaian Sengketa Konsumen Ditinjau dari Hukum Acara Serta Kendala Implementasinya, Penerbit Kencana, Jakarta. hlm. 95. pelaku usaha yang berkaitan dengan pembuatan produk yang terjadi karena kesalahan, kelalaian dan kurang hatihati, sehingga mewajibkan pelaku usaha sebagai pembuat produk menanggung segala akibatnya sebagai resiko dari perbuatan tersebut.

\subsection{Upaya Penyelesaian Sengketa Yang Dapat Ditempuh Oleh Konsumen Bila Terjadi Shortweighting}

Undang-Undang Nomor 8 tahun 1999 membagi penyelesaian sengketa konsumen menjadi 2 bagian, yaitu:

1) Penyelesaian sengketa secara damai oleh para pihak sendiri dapat dibagi menjadi dua yaitu :

a. Penyelesaian sengketa secara damai oleh para pihak sendiri.

Susanti Adi Nugroho menyebutkan bahwa yang dimaksud dengan penyelesaian secara damai adalah penyelesaian yang dilakukan oleh kedua belah pihak yang bersengketa (pelaku usaha dan konsumen) tanpa melalui pengadilan atau badan penyelesaian sengketa konsumen dan tidak bertentangan dengan Undang-Undang Perlindungan Konsumen. ${ }^{24}$

Istilah penyelesaian damai oleh para pihak ini sering disebut dengan negoisasi. Negoisasi adalah proses konsensus yang digunakan para pihak untuk

$24 \quad$ Ibid, hlm. 99. 
memperoleh kesepakatan di antaramereka. Negoisasimenurut Roger Fisher dan Willian Ury adalah komunikasi dua arah yang dirancang untuk mencapai kesepakatan yang sama maupun berbeda. Negoisasi merupakan sarana bagi pihak-pihak yang mengalami sengketa untuk mendiskusikan penyelesaiannya tanpa melibatkan pihak ketiga penengah yang tidak berwenang mengambil keputusan (mediasi) dan pihak ketiga pengambil keputusan (arbitrase dan litigasi). ${ }^{25}$

Negoisasibiasanyadipergunakan dalam sengketa yang tidak terlalu pelik, di mana para pihak masih beritikad baik untuk duduk bersama dan memecahkan masalah. Negoisasi dilakukan apabila komunikasi antar pihak yang bersengketa masih terjalin dengan baik, masih ada rasa saling percaya da ada keinginan untuk cepat mendapatkan kesepakatan dan meneruskan hubungan baik. $^{26}$

b. Penyelesaian sengketa melalui lembaga yang berwenang.

Susanti Adi Nugroho menyebutkan bahwa penyelesaian sengketa melalui lembaga yang berwenang yaitumelaluiBadanPenyelesaian

25 Celina Tri Siwi Kristiyanti., 2008, Hukum Perlindungan Konsumen. Sinar Grafika, Jakarta.h. 188, hlm. 188.

26 Ibid.
Sengketa Konsumen (untuk selanjutnya disingkat dengan BPSK) dimana penyelesaiannya dengan menggunakan mekanisme melalui mediasi, konsiliasi atau arbitrase. ${ }^{27}$

Penyelesaiansengketakonsumen dengan adanya BPSK maka dapat dilakukan secara cepat, mudah dan murah. Cepat karena undang-undang menentukan dalam tenggang waktu 21 hari kerja, BPSK wajib memberikan putusannya. Mudah karena prosedur administratif dan proses pengambilan putusan yang sangat sederhana. Murah terletak pada biaya perkara yang terjangkau. Penyelesaian sengketa konsumen di BPSK diselenggarakan untuk mencapai kesepakatan mengenai bentuk dan besarnya ganti-kerugian dan/atau mengenai tindakan tertentu untuk menjamin tidak akan terulang kembali kerugian yang diderita oleh konsumen. Bentuk jaminan yang dimaksud adalah berupa pernyataan tertulis yang menerangkan bahwa tidak akan terulang kembali perbuatan yang telah merugikan konsumen tersebut.

Mekanisme penyelesaian sengketa melalui BPSK, dapat diuraikan sebagai berikut; bahwa dalam menangani dan menyelesaikan sengketa konsumen BPSK membentuk majelis, dengan jumlah anggota yang harus berjumlah ganjil, yaitu terdiri dari sedikit-dikitnya 3 (tiga) orang yang mewakili semua unsur, dan dibantu oleh seorang panitera. Menurut

27 Susanti Adi Nugroho, op. cit, hlm.98. 
ketentuan Pasal 54 Ayat (4), ketentuan teknis dari pelaksanaan tugas majelis BPSK yang akan menangani dan menyelesaikan sengketa konsumen akan diatur tersendiri oleh Menteri Perindustrian dan Perdagangan. Yang jelas BPSK diwajibkan untuk menyelesaikan sengketa konsumen yang diserahkan kepadanya dalam jangka waktu 21 (dua puluh satu) hari terhitung sejak gugatan diterima oleh BPSK. $^{28}$

Lembaga penyelesaian diluar pengadilan, yang dilaksanakan melalui Badan Penyelesaian Sengketa Konsumen ini memang dikhususkan bagi konsumen perorangan yang memiliki perselisihan dengan pelaku usaha. Sifat penyelesaian sengketa yang cepat dan murah yang memang dibutuhkan oleh konsumen, terutama konsumen perorangan, tampaknya sudah cukup terakomodasi dalam Undang-Undang Perlindungan Konsumen. ${ }^{29}$

2) Penyelesaian sengketa konsumen melalui proses litigasi.

Penyelesaian sengketakonsumen melalui pengadilan (Pasal 48 Undang-Undang Perlindungan Konsumen), memiliki makna bahwa penyelesaian sengketa konsumen melalui pengadilan hanya dimungkinkan apabila :

a. Para pihak belum memilih upaya penyelesaian sengketa konsumen diluar pengadilan.

28 Yusuf Sofie, op. cit, hlm. 88

29 Rahmadi Usman, 2003, Pilihan Penyelesaian Sengketa di Luar Pengadilan, PT Citra Aditya Bakti, Bandung, hlm. 40. b. Upaya penyelesaian sengketa konsumen di luar pengadilan, dinyatakan tidak berhasil oleh salah satu pihak atau oleh para pihak yang bersengketa. ${ }^{30}$

Satuhalyangharusdiingat,bahwa cara penyelesaian sengketa melalui pengadilan menggunakan hukum acara umum yang berlaku selama ini, yaitu HIR/RBg. Pasal 45 ayat (4) UndangUndang Perlindungan Konsumen, yang menyatakan bahwa "apabila telah dipilih upaya penyelesaian sengketa konsumen diluar pengadilan, gugatan melalui pengadilan hanya dapat ditempuh apabila upaya tersebut dinyatakan tidak berhasil oleh salah satu pihak atau oleh para pihak yang bersengketa." Menurut Ahmadi Miru dan Sutarman Yodo, ketentuan tersebut hanya dapat dibenarkan apabila istilah "tidak berhasil" tertuju pada BPSK yang tidak berhasil memberi putusan dalam cara arbitrase, atau BPSK sebagai mediator atau konsiliator, tidak berhasil mengantar para pihak mencapai kesepakatan. ${ }^{31}$

Mekanisme penyelesaian sengketa melalui pengadilan, dapat diuraikan sebagai berikut; bahwa dalam Pasal 54 Ayat (3) Undang-Undang Perlindungan Konsumen dikatakan bahwa putusan yang dijatuhkan majelis (BPSK) bersifat final dan mengikat. Walaupun demikian, para

30 Sudaryatmo, 1996, Masalah Perlindungan di Indonesia, Penerbit Citra Aditya Bakti, Bandung, hlm. 19.

31 Susanti Adi Nugroho, op cit, hlm. 105 
pihak yang tidak setuju atas putusan tersebut dapat mengajukan keberatan kepada Pengadilan Negeri untuk diputus. Terhadap putusan Pengadilan Negeri Ini, meskipun dikatakan bahwa Undang-Undang tentang Perlindungan Konsumen hanya memberikan hak kepada pihak yang tidak merasa puas atas putusan tersebut untukmengajukan kasasi ke Mahkamah Agung, namun dengan mengingat akan relativitas dari tidak "merasa puas", peluang untuk mengajukan kasasi sebenarnya terbuka bagi setiap pihak dalam perkara. ${ }^{32}$

Undang-Undang tentang

Perlindungan Konsumen juga telah memberikan jangka waktu yang pasti bagi penyelesaian perselisihan konsumen yang timbul, yakni 21 (dua puluh satu) hari untuk proses pada tingkat Pengadilan Negeri, dan 30 ( tiga puluh ) hari untuk diselesaikan oleh Mahkamah Agung, dengan "jeda" masing-masing 14 (empat belas) hari untuk mengajukan keberatan ke Pengadilan Negeri maupun kasasi ke Mahkamah Agung. ${ }^{33}$

Menurut Pasal 54 Ayat (3) Undang-Undang Perlindungan Konsumen, menentukan bahwa "putusan Majelis Badan Penyelesaian Sengketa Konsumen bersifat final dan mengikat." Pada penjelasan Pasal 54 Ayat (3) Undang-Undang Perlindungan Konsumen, ditegaskan bahwa "kata bersifat final berarti

32 Rahmadi Usman, op. cit, hlm. 49.

33 Sidharta, 2004, Hukum Perlindungan Konsumen Indonesia, PT. Gramedia Pustaka Utama, Jakarta, hlm. 38. tidak ada upaya banding dan kasasi". Namun ternyata, Undang-Undang Perlindungan Konsumen mengenal pengajuan keberatan kepada Pengadilan Negeri. ${ }^{34}$

Apabila pelaku usaha menerima (menyetujui atau sependapat) dictum (amar, isi) putusan Badan Penyelesaian Sengketa Konsumen (Pasal 56 ayat (1) Undang-Undang Perlindungan Konsumen), maka ia wajib melaksanakan putusan tersebut. Jika pelaku usaha tidak menggunakan upaya hukum yang ada (banding dan selanjutnya kasasi), maka putusan Badan Penyelesaian Sengketa Konsumen menjadi berkekuatan hukum tetap. Tidak dilaksanakannya putusan tersebut, apalagi setelah dilakukannya fiat eksekusi berdasarkan Pasal57 Undang-Undang Perlindungan Konsumen, merupakan tindak pidana di bidang perlindungan konsumen. ${ }^{35}$

\section{KESIMPULAN}

Bertanggung jawab terhadap kerugian konsumen apabila timbul praktik penjualan shortweighting, adalah produsen dan/atau pelaku usaha yang memperdagangkan barang tersebut kepada konsumen yang mana hal tersebut tergantung pada pembuktian lebih lanjut terhadap ada/ tidak adanya unsur kesalahan dari masing-masing pelaku usaha. Sistem

34 Ridwan Halim, 2003, Filsafat Hukum, Penerbit Pelita Studiways, Jakarta, hlm. 34.

35 Priyatna Abdurrasyid, 2002, Arbitrase dan Alternatif Penyelesaian Sengketa, Penerbit PT Fikahati Aneska dan Badan Arbitrase Nasional, Jakarta, hlm. 67. 
pembuktian yang digunakan dalam penyelesaian sengketa konsumen adalah sistem pembuktian terbalik sesuai dengan ketentuan dalam Pasal 19 dan Pasal 22 Undang-Undang Perlindungan Konsumen. Tanggung jawab pelaku usaha terhadap konsumen atas tuntutan ganti rugi tertuang dalam Pasal24Undang-Undang Perlindungan Konsumen.

Upaya penyelesaian sengketa oleh konsumen terkait dengan shortweighting dapat ditempuh melalui dua cara yaitu penyelesaian sengketa diluar pengadilan dan penyelesaian sengketa konsumen melalui proses litigasi, Penyelesaian sengketa di luar pengadilan yaitu bisa melalui penyelesaian sengketa secara damai oleh pahak pihak sendiri dan bisa melalui Badan Penyelesaian Sengketa Konsumen (BPSK).

\section{DAFTAR PUSTAKA}

\section{BUKU}

Ibrahim, J. (2006). Teori dan metodologi penelitian hukum normatif. Malang: Bayumedia Publishing.

Munir, F. (1996). Hukum Bisnis Dalam Teori Dan Praktek. CitraAditya Bakti, Bandung.

Marzuki, P. (2009). Mahmud. Penelitian Hukum. Kencana Prenada Media Group, Jakarta.

Nugroho, S. A. (2008). Proses penyelesaian sengketa konsumen ditinjau dari hukum acara serta kendala implementasinya. Kencana. Jakarta.

Priyatna, A. (2002). Arbitrase dan Alternatif Penyelesaian Sengketa. Fikahati Aneska, Jakarta.

Rahmadi, U. (2004). Hukum Persaingan Usaha Di Indonesia. PT. Gramedia Pustaka Utama, Jakarta.

Rajagukguk, E. (2000). Hukum perlindungan konsumen. Bandung: Mandar Maju. Bandung.

RidwanHalim.(2003).FilsafatHukum, Penerbit Pelita Studiways, Jakarta.

Shofie, Y. (2000). Perlindungan Konsumen dan Instrumeninstrumen hukumnya. Citra Aditya Bakti. Bandung.

Sidharta, (2004), Hukum Perlindungan Konsumen Indonesia, PT. Gramedia Pustaka Utama, Jakarta.

Siwi, K. C. T. (2008). Hukum Perlindungan Konsumen. Sinar Grafika, Jakarta.

Soekanto, S. (2006). Pengantar penelitian hukum. Penerbit Universitas Indonesia (UIPress).

Sudaryatmo. (1996). Masalah Perlindungan di Indonesia. Penerbit Citra Aditya Bakti. Bandung.

Sumarwan, U. (2003). Perilaku konsumen: Teori dan penerapannya dalam pemasaran. 
Jakarta: Ghalia Indonesia.

Usman,R.(2003).PilihanPenyelesaian

Sengketa di Luar Pengadilan.

Citra Aditya Bakti. Bandung.

Wahyuni, E. S. (2003). Aspek hukum

sertifikasi dan keterkaitannya dengan perlindungan konsumen.

Citra Aditya Bakti. Bandung.

Wirasasmita, H. R. (2002). Kamus

lengkap ekonomi. Pionir Jaya.

Bandung

\section{PERATURAN}

\section{PERUNDANG-UNDANGAN}

Undang-Undang Nomor 8 Tahun 1999 tentang Perlindungan Konsumen, Lembaran Negara Republik Indonesia Tahun 1999 Nomor 42. Tambahan Lembaran Republik Indonesia Nomor 3821.

Kitab Undang-Undang Hukum Perdata (KUHPerdata)

\section{ARTIKEL JURNAL}

Brotosusilo, A. (2017). Hak-hak Produsen Dalam Hukum Perlindungan Konsumen. Jurnal Hukum \& Pembangunan, 22(5), 423-439.

Pande, N. (2017). PERLINDUNGAN KONSUMEN TERHADAP PRODUK KOSMETIK IMPOR YANG TIDAK TERDAFTAR DIBBPOMDENPASAR.Jurnal Magister Hukum Udayana (Udayana Master Law Journal), 6(1), 13 - 22. doi:10.24843/ JMHU.2017.v06.i01.p02.
Yogiartha, G. (2016). TANGGUNGJAWAB PELAKU USAHA TERKAIT DENGAN JUALBELI TELEPON SELULER TANPA GARANSI. Jurnal Magister Hukum Udayana (Udayana Master Law Journal), 5(1), 93 - 100. doi:10.24843/ JMHU.2016.v05.i01.p09

\section{INTERNET}

Sularsi, SH, Senior Staff YLKI http:// ylki.or.id/2011/11/membelib a rang - da la m - ke a d a a n terbungkus/, diakses tanggal 4 Desember 2017

YDH, 2017, http://news.metrotvnews. $\mathrm{com} / \mathrm{read} / 2017 / 10 / 04 / 767975 /$ ylki-minta-polisi-usut-ledakangudang-pengisian-elpiji, diakses tanggal 4 Desember 2017. 